\title{
Penyelesaian Sengketa Pelaksanaan Perjanjian Lelang Sungai di Bidang Perikanan di Kecamatan Tanjung Lago Kabupaten Banyuasin
}

\author{
Indrajaya \\ Fakultas hukum Universitas Muhammadiyah Palembang \\ Correspondence email: indrajaya.palembang@gmail.com
}

\begin{abstract}
Abstrak. Dalam KUHPerdata mengatur tenang perjanjian, salah satu jenis perjanjian adalah lelang, namun obyek perjanjian lelang ini bukanlah benda atau hewan, melainkan sungai. Di wilayah yang memilik sumber daya alam berupa sungai, perjanian ini sering dilaksanakan, di dalam praktek disesuaikan dengan kearipan lokal setempat. Tradisi lelang sungai di Kecamatan Tanjung Lago Kabupaten Banyuasin Provinsi Sumatera Selatan sudah berjalan cukup lama dan sudah menjadi tradisi bagi penduduk setempat. Namun dalam prakteknya masih sering terjadi wanprestasi yang dilakukan para pihak. Tujuan Penelitian ini untuk mengetahui penyelesaian perselisihan jika terjadi wanprestasi yang dilakukan para pihak. Metode penelitian adalah dengan melihat fakta langsung yang tejadi secara nyata tetapi tetap dengan menggunakan bahan hukum berupa peraturan yang ada serta sumber - sumber lainnya.Dari hasil penelitian diketahui bahwa jika salah satu pihak (pemerintahan desa dengan pemenang lelang) melakukan wanprestasi maka akan dilakukan musyawarah antara kedua belah pihak tapi jika tidak dapat diselesaikan maka dapat tempuh jalur hukum. Sedangkan jika terjadi wanprestasi antara pemenang lelang dan nelayan, maka penyelesaiannya hanya berupa teguran dan hilangnya kepercayaan tanpa adanya sanksi.
\end{abstract}

Kata Kunci: Penyelesaian sengketa; Perjanjian; Lelang Sungai

\begin{abstract}
In the Civil Code regulates agreement, one type of agreement is an auction, however the object of this auction agreement is not an object or animal, but a river. In areas that have natural resources in the form of rivers, these agreements are often carried out, in practice adapted to local local wisdom. The river auction tradition in Tanjung Lago District, Banyuasin Regency, South Sumatra Province has been going on for a long time and has become a tradition for the local population. However, in practice there are often defaults committed by the parties. The purpose of this study is to determine the settlement of disputes in case of default by the parties. The research method is to look at direct facts that happen in real terms but still by using legal materials in the form of existing regulations and other sources. From the research results it is known that if one of the parties (the village administration and the winner of the auction) defaults, a deliberation between both parties but if it cannot be resolved then legal action can be taken. Meanwhile, if there is a default between the auction winner and the fisherman, the settlement will only be in the form of a warning and loss of trust without any sanctions.
\end{abstract}

Keywords: Dispute resolution; Agreement; River Auction

\section{PENDAHULUAN}

Sebagaimana diatur dalam KUH Perdata khususnya Buku III, yaitu mengenai perikatan yang mengatur tentang ketentuan - ketentuan umum khususnya dalam empat bab serta lima belas bab tentang adanya aturan tentang ketentuan -ketentuan khusus. ${ }^{1}$

Istilah perikatan dalam KUH Perdata diambil dari kata "van verbintenissen". Istilah ini dalam KUH Perdata merupakan serapan dari istilah obligation dalam Code Civil Perancis, istilah mana diambil dari hukum Romawi yang terkenal dengan istilah obligation. ${ }^{2}$

Dalam prakteknya, istilah verbintenis dalam KUH Perdata diterjemahkan berbeda-beda dalam literatur kepustakaan hukum Indonesia. Ada yang mengistilahkan Verbitenis dengan perutangan, ${ }^{3}$ ada juga yang mengistilahkannya dalam pengertian perjanjian ${ }^{4}$ serta juga ada yang memberikan pengertiannya dengan kata perikatan. ${ }^{5}$ Penggunaan istilah kata perikatan untuk verbintenis dalam prakteknya kelihatannya lebih umum dipakai dalam khasana ilmu hukum di Indonesia.

Dalam hal perjanjian sebagaimana yang diatur Hukum Perdata memang mencakup banyak hal, salah satunya mencangkup tentang perjanjian lelang. Lelang yang dimaksud adalah salah satu bentuk perjanjian, tapi obyek

${ }^{1}$ RM.Suryodiningrat, Azas-Azas Hukum Perikatan, (Bandung: Tarsito, 1985), hlm. 11

${ }^{2}$ R. Soetojo Prawirohamidjojo, Hukum Perikatan, (Surabaya: Bina Ilmu, 1979), hlm. 10.

3 Ny. Sri Soedewi M. Sofwan, Hukum Perutangan, terjemahan Verbintenissenrecht bagian dari Inleiding Nederlands Burgerlijk Rccht oleh Mr. Dr. HFA Vollmar, Yogyakarta: Seksi Hukum Perdata Fak. Hukum UGM, 1975, hlm 37 dan lihat buku E. Utrecht, Pengantar Dalam Hukum Indonesia, Jakarta: Ikhtiar, cet. IV, 1957, hlm. 252.

${ }^{4}$ Achmad Ichsan, Hukum Perdata IB, (Jakrta, Pembimbing Masa, 1969), hlm. 7

${ }^{5}$ Subekti dan R. Tjiptasudibio, Kitab Unidang-undang Hukum Perdata terjemahanBurgerlijk Wetboek. Mariam Danu Badrul-zaman, Buku III Hukum Perikatan Dengan Penjelasan, Bandung, Alumni, 1983 
perjanjian lelang ini bukan benda atau hewan, melainkan sungai. Dalam prakteknya, tradisi lelang sungai ini sudah dilakukan cukup lama terutama di Kecamatan Tanjung Lago Kabupaten Banyuasin Provinsi Sumatera Selatan.

Meskipun sebagian besar wilayah di Indonesia merupakan daerah perairan namun tradisi lelang sungai ini tidak mudah dijumpai di Indonesia, karena itu dengan adanya tradisi ini yang memiliki ciri khas yang berbeda dari wilayah perairan lainnya yang ada di nusantara ini. Hal ini ada dan menjadi kearifan lokal dan menjadi budaya, yang patut dilestarikan. Sehungga membuat wilayah ini menjadi terkenal akan warisan budaya yang turun-temurun.

Dengan semakin berkembangnya zaman maka dari itu hasil sungai yang melimpah dimiliki Desa Bunga Karang ini diharapkan dapat meningkatkan tingkat perekonomian masyarakat desa, terutama para nelayan.

Nelayan adalah mereka yang mata pencaharian pokoknya di bidang penangkapan ikan dan yang hidup di daerah perairan atau pantai yang secara geografis masyarakat nelayan adalah masyarakat yang hidup, tumbuh dan berkembang di kawasan pesisir, yakni suatu kawasan transisi antara wilayah darat dan laut ${ }^{6}$. Sesuai dengan lokasi yang diambil Kecamatan Tanjung Lago yang mayoritas penduduknya berdiam di pinggir sungai atau lebih dikenal masyarakat pesisir. Para nelayan disini didominasi oleh nelayan tradisional sebagai pelaku usaha perikanan, kegiatan ekonomi penduduk yang utama dilakukan adalah menangkap ikan.

Dalam prakteknya, dengan mayoritas penduduk bermata pencaharian nelayan yang hanya dilakukan secara tradisional maka perekonomian di desa bunga karang tidak berjalan baik, kurangnya pembeli membuat sumber daya yang melimpah seakan tidak menguntungkan bagi masyarakat desa terutama para nelayan, Hal ini dikarenakan kesulitan dalam pemasaran hasil tangkapan mereka. Oleh karena Memudahkan penjualan hasil tangkapan nelayan maka Pemerintah Kecamatan Tanjung Lago mengadakan lelang sungai yang di khususkan hanya bagi putera daerah atau masyarakat asli daerah tersebut, dengan tujuan pemenang lelang sebagai jembatan bagi para nelayan untuk penjualan hasil tangkapan ikan jaringan pasar yang lebih luas. Hal ini bukan tanpa alasan karena biasanya pemenang lelang suangi adalah mereka yang memiliki jaringan dan modal besar, sehingga dengan mudah hasil ikan yang didapat akan di Psarkan ke berbagai daerah khsusnya di Sumatera Selatan.

Lelang merupakan suatu proses jual beli barang atau jasa dengan cara membuka penawaran yang kemudian dijual pada penawar dengan harga tertinggi. Terdapat beberapa macam variasi lelang yang bergantung pada batas minimum penawaran, durasi lelang, hingga cara penentuan pemenang dari lelang ini. ${ }^{7}$

Berdasarkan Peraturan Menteri Keuangan Nomor 27/PMK.06/2016 tentang Petunjuk Pelaksanaan Lelang, lelang adalah penjualan barang yang terbuka untuk umum dengan penawaran harga secara tertulis dan/ atau lisan yang semakin meningkat atau menurun untuk mencapai harga tertinggi, yang didahului dengan pengumuman lelang biasanya lelang dilakukan dengan datang ke tempat lelang, melakukan proses administrasi, dan mengikuti lelang di lokasi dengan mengacungkan tangan atau menunjukkan nomor peserta lelang. ${ }^{8}$

Tujuan dilakukannya lelang bukan hanya untuk mencari pengepul untuk nelayan sebagai jembatan penjualan ikan ke pasar tapi untuk menciptakan perekonomian yang mandiri dengan melibatkan semua warga untuk mengelola asil alam mereka sendiri agar tercipta perekonomian yang baik dengan asas kepercayaan.

Perjanjian atau kontrak adalah suatu peristiwa dimana seseorang berjanji ke pada seorang lain atau dimana dua orang itu saling berjanji untuk melaksanakan suatu hal ${ }^{9}$. Mengenai bentuk suatu perjanjian tidak ada ketentuan yang mengikat, karena itu perjanjian dapat di buat secara lisan dan tulisan. Dalam hal dibuat secara tertulis, perjanjian mempunyai makna sebagai alat bukti bila pihak-pihak dalam perjanjian itu mengalami perselisihan. Untuk perjanjian tertentu, undang-undang menentukan bentuk tersendiri sehingga bila bentuk itu di ingkari maka perjanjian tersebut tidak $s^{10}{ }^{10}$. Dengan demikian bentuk tertulis suatu perjanjian tidak sebagai alat pembuktian, tetapi juga untuk memenuhi syarat adanya peristiwa (perjanjian)

Menurut Pasal 1313 KUHPerdata,perjanian adalah Perbuatan dengan mana satu orang atau lebih mengikatkan dirinya terhadap satu orang lain atau lebih. Dari peristiwa ini, timbullah suatu hubungan hukum antara dua orang atau lebih yang disebut Perikatan yang di dalamya tersedia hak dan masing-masing pihak. ${ }^{11}$

Berdasarkan pada asas kebebasan berkontrak dalam Pasal 1338 KUHPerdata, para pihak dalam kontrak bebas untuk membuat perjanjian, apapun isi dan bagaimanapun bentuknya: "Semua perjanjian yang dibuat secara sah

\footnotetext{
${ }^{6}$ Kusnadi. Keberdayaan Nelayan \& Dinamika Ekonomi Pesisir . (Jember. Ar-ruzz Media, 2009), hlm 7

${ }^{7} \mathrm{Nm}$ Wahyu Kuncoro, Resiko Jual Beli Property, (Jakarta, Raih Asa Sukses. 2015) hlm 265

${ }^{8} \mathrm{Ni}$ Kadek Ayu Ena Widiasih, I Made Sarjana. Risalah Lelang Sebagai Akta Otentik engganti Akta Jual Beli Dalam Lelang. Journal Ilmu Hukum.Bali, 2016, hlm.3

${ }^{9}$ I Ketut Oka Setiawan, Hukum Perikatan, (Jakarta, Sinar Grafika, 2017). hlm 42

${ }^{10}$ Ibid.hlm43

${ }^{11}$ Soesilo,Pramudji, Kitab Undang-Undang Hukum Perdata, Rhedbook Publisher Buku Ke 3, 2008, hlm 298
} 
berlaku bagi undang-undang bagi mereka yang membuatnya." Akan tetapi, yang perlu kita ingat bahwa asas kebebasan berkontrak tersebut tetap tidak boleh melanggar syarat-syarat sahnya perjanjian dalam KUHPerdata. ${ }^{12}$

Syarat sahnya suatu perjanjian sebagaimana diatur dalam Pasal 1320 - Pasal 1337 KUHPerdata, yaitu :

1. Kesepakatan para pihak. Kesepakatan ini berarti ada persesuaian kehendak yang bebas antara para pihak mengenai hal-hal pokok yang diinginkan dalam perjanjian. Dalam hal ini, antara para pihak harus mempunyai kemauan yang bebas (sukarela) untuk mengikatkan diri, di mana kesepakatan itu dapat dinyatakan secara tegas maupun diamdiam. Bebas di sini artinya adalah bebas dari kekhilafan (dwaling, mistake), paksaan (dwang, dures), dan penipuan (bedrog, fraud). Secara a contrario, berdasarkan Pasal 1321 KUHPerdata, perjanjian menjadi tidak sah, apabila kesepakatan terjadi karena adanya unsur-unsur kekhilafan, paksaan, atau penipuan.

2. Kecakapan para pihak. Menurut Pasal 1329 KUHPerdata, pada dasarnya semua orang cakap dalam membuat perjanjian, kecuali ditentukan tidak cakap menurut undang-undang.

3. Mengenai suatu hal tertentu. Hal tertentu artinya adalah apa yang diperjanjikan hak-hak dan kewajiban kedua belah pihak, yang paling tidak barang yang dimaksudkan dalam perjanjian ditentukan jenisnya. Menurut Pasal 1333 KUHPerdata, objek perjanjian tersebut harus mencakup pokok barang tertentu yang sekurang-kurangnya dapat ditentukan jenisnya. Pasal 1332 KUHPerdata menentukan bahwa objek perjanjian adalah barang-barang yang dapat diperdagangkan.

4. Sebab yang halal. Sebab yang halal adalah isi perjanjian itu sendiri, yang menggambarkan tujuan yang akan dicapai oleh para pihak. Isi dari perjanjian itu tidak bertentangan dengan undang-undang, kesusilaan, maupun dengan ketertiban umum. Hal ini diatur dalam Pasal 1337 KUHPerdata $^{13}$

Dalam prakteknya perjanjian lelang sungai yang dibuat para pihak di Kecamatan Tanjung Lago Kabupaten Banyuasin dilakukan dengan cara lisan atau dengan kata lain hanya menggunakan asas kepercayaan dari para pihak yang berjanji. Hal ini sulit untuk metegakkan sanksinya jika dikemudian hari terjadi wanprestasi yang dilakukan salah satu pihak. Oleh karena itu tanpa adanya sanksi hukum yang tegas maka perjanjian itu tidak akan berjalan secara maksimal bahkan perjanjian itu akan selalu dianggap lemah di mata hukum maupun di mata orang-orang yang terikat dalam perjanjian tersebut.

\section{METODE}

Dalam kegiatan penelitian, khususnya penelitian ilmiah, pasti menggunakan metode yang logis dan sistematis. Secara etimologi metodelogi berasal dari bahasa Yunani, yaitu methodus dan logos yang memiliki arti cara kerja bertujuan untuk memahami obyek sasaran yang bersangkutan. Penelitian jurnal ini menggunakan metode hukum normatif empiris yaitu gabungan pendekatan normatif dengan adanya penambahan berbagai unsur empiris ${ }^{14}$. Metode penelitian ini mengenai implementasi ketentuan hukum normatif dalam aksinya pada setiap peristiwa hukum tertentu yang terjadi dalam suatu masyarakat.

\section{HASIL DAN PEMBAHASAN}

Desa Bunga Karang Kecamatan Tanjung Lago terletak di Kabupaten Banyuasin dengan luas wilayah 82.010 (ha) dengan jumlah penduduk 36.259 jiwa yang mayoritas tinggal di pesisir sungai menjadikan Desa Bunga Karang Kecamatan Tanjung Lago sebagai desa yang mayoritas penduduknya bermatapencaharian sebagai nelayan tradisional. Dengan demikian pemerintah desa yang terdahulu yang di pimpin oleh seorang Persirah dan pemangku adat mempunyai pemikiran untuk mengelola sumber daya yang ada untuk di manfaatkan sebaik mungkin dengan cara mengelola secara langsung tanpa bantuan orang dari luar daerah agar masyarakat sekitar dapat mandiri dengen mengelola hasil kekayaan alam daerahnya sendiri dan salah satu cara untuk membuka lapangan pekerjaan bagi masyarakat sekitar

Pelaksanaan lelang sungai di bidang perikanan merupakan kearifan lokal yang berada di Desa Bunga Karang Kecamatan Tanjung Lago Kabupaten Banyuasin yang sudah ada sejak lama sebelum Kabupaten Banyuasin itu sendiri berdiri lelang di Desa Bunga Karang Kecamatan Tanjung Lago yang dilaksanakan setiap tahun dengan objek lelang nya adalah sungai, di tiap-tiap desa memiliki batas wilayah lelangnya masing- masing. Untuk menentukan wilayah lelang setiap desa memiliki tim yang terdiri dari koordinator (kades), sekretaris, bendahara, anggota dan ketua lelang sungai. ${ }^{15}$

${ }^{12}$ Suyanto, Hapusnya Hak Atas Tanah Akibat Penitipan Ganti Rugi Dalam Pengadaan Tanah Untuk Kepentingan Umum, (Surabaya, Cv Jagad Publishing, 2020), hlm 165

${ }^{13}$ Retna Gumanti, Syarat Sahnya Perjanjian (Ditinjau Dari KUHPerdata).Jurnal Pelangi Ilmu. Vol 05, 2012, hlm 4

${ }^{14}$ Soekanto, Soejono, Pengantar Penelitian Hukum, Universitas Indonesia (UI) Press, Jakarta 1986, hlm. 27

${ }^{15}$ Hasil Wawancara Dengan Kepala Desa Bunga Karang di Desa Bunga Karang Pada Tanggal 10 Agustus 2020. Pukul $10.30 \mathrm{Wib}$ 
Dalam pelaksanaanya Tim tersbut bertugas untuk menentukan batas-batas wilayah yang akan dilelang dan tim tersebut juga bertugas sebagai yang membuat perjanjian dan peraturan didalam lelang, dalam pelaksanaanya perjanjian di buat dengan bermusyawarah dengan masyarakat sekitar, perjanjian yang di muat dalam lelang sungai di Desa Bunga Karang Kecamatan Tanjung Lago adalah asas kebebasan berkontrak dalam pelaksanaan perjanjiannya dengan demikian hukuman yang diterima adalah kehilangannya kepercayaan, dalam pelaksanaanya Perjanjian adalah suatu peristiwa dimana seseorang berjanji ke pada seorang lain atau dimana dua orang itu saling berjanji untuk melaksanakan suatu hal. Mengenai bentuk suatu perjanjian tidak ada ketentuan yang mengikat, karena itu perjanjian dapat di buat secara lisan dan tulisan. ${ }^{16}$

Menurut tokoh adat dan tokoh masyarakat setemapat, lelang sungai ini sudah ada sejak lama sebelum Kabupaten Banyuasin berdiri, dahulunya lelang sungai ini masih menggunakan hukum adat sebagai penyelesaiannya apabila ada yang melanggar, hukum adat lah yang menjadi acuan untuk sanksi bagi para pelanggar, namun seiring waktu peraturan adat di anggap tidak memiliki sanksi yang tegas dan dirasa tidak cukup kuat untuk mengikat pihakpihak yang terlibat dalam perjanjian lelang tersebut. ${ }^{17}$

Seiring berjalannya waktu hukum adat yang menjadi landasan hukum dari lelang sungai sekarang sudah beralih menjadi perjanjian tertulis yang di buat secara seksama oleh pemerintah desa di bantu tokoh adat dan masyarakat desa namun karena kurangnya pemahaman hukum, membuat perjanjian tersebut dirasa penulis masih kurang karena peraturan tersebut hanya mengikat dua pihak saja yaitu pemerintah desa dan pemenang leleng, sedangkan nelayan memiliki kebeasan tanpa adanya peraturan yang mengikat nelayan agar tidak bersikap sewena-wena.

Menurut effendi selaku kepala dusun perjanjian tersebut hanya memuat perjanjian antara pemenang lelang dan pemerintah desa yang di tanda tangani oleh kedua belah pihak, sedangkan perjanjian antara pemenang lelang dengan nelayan tidak ada, hanya membuat perjanjian memalui lisan saja. ${ }^{18}$

Menurut Ismail selaku nelayan tidak adanya perjanjian tertulis yang mengikat membuat nelayan menjadi bebas melakukan aktivitas mencari ikan, dan tidak ada sanksi apapun membuat nelayan merasa tidak ada hal yang harus di takutkan. ${ }^{19}$

Menurut kepala desa,mengatakan sanki yang akan di terima oleh pelanggaran lelang yaitu di beri teguran atas pelanggaran ringan, jika pelanggaran di anggap berat maka pemenang lelang akan di ancam tidak dapat mengikuti kembali lelang di tahun-tahun berikutnya dan pemenang lelang akan di laporkan kepihak yang berwajib.

Menurut Iwan selaku pemenang lelang, sebagai pemenang lelang sebenarnya merasa keberatan dengan isi perjanjian tersebut karena pemenang lelang harus bertanggung jawab atas apapun kegiatan yang dilakukan nelayan dalam mencari ikan, jika ada yang melanggar peraturan dengan menggunakan racun, bom, atau setrum listrik jika ketahuan pihak desa maka yang akan bertanggung jawab atas tindakan itu adalah pemenang lelang.

Jadi pemenang lelang akan menerima sanksi teguran sampai yang terberat adalah pemenjaraan jika terbukti melanggar isi dalam perjanjian tersebut, akan tetapi nelayan yang mempunyai pengaruh penting dalam perjanjian hanya mendapatkan sanksi teguran dan larangan mencari ikan oleh pemenang lelang di sungai yang di menangkannya, hal ini menurut penulis di anggap tidak relevan karena ada pihak yang di rugikan oleh tindakan nelayan jika melakukan kegiatan mencari ikan secara illegal dengan menggunakan alat-alat yang di anggap berbahaya dan merusak ekositem ikan dan lingkungan sekitarnya.

Maka dari itu pemerintah desa selaku badan yang membuat peraturan harus membuat perjanjian khusus untuk pemenang lelang dan nelayan agar tidak ada yang merasa di rugikan dari tindakan yang dilakukan masing-masing, dan agar adanya rasa kesinambungan antar sesama. Adanya sanksi di setiap pelanggaran dan memiliki efek jerah, membuat setiap pelaku yang akan melalakukan berfikir akan dampak dari apa yang mereka lakukan dan harus bertanggung jawab atas tindakan apa yang mereka lakukan. Dengan begitu tidak akan ada lagi tindakan semena-mena yang di lakukan dan tidak akan merugikan pihak manapun.

\section{SIMPULAN}

Dari uraian latar belakang dan hasil pembahasan maka dapat disimpulkan bahwa Penyelesaian perselisihan lelang sungai apabila ada salah satu pihak yang wanprestasi dalam pelaksanaan perjanjian lelang sungai dibidang perikanan antara pemenang lelang, nelayan, dan Pemerintah desa yaitu antara pemerintah desa dan pemenang lelang jika salah satu pihak ada yang wanprestasi maka akan di lakukan musyawarah antara kedua belah pihak apa bila tidak dapat diselesaikan maka dapat mengambil jalur hukum. Sedangkan jika terjadi perselisihan antara pemenang lelang dan nelayan maka penyelesaiannya hanya berupa teguran dan akan hilangnya kepercayaan dari salah satu pihak tanpa adanya sanksi

\footnotetext{
${ }^{16}$ I Ketut Oka Setiawan,loc.cit.hlm. 42

${ }^{17}$ Hasil Wawancara Tokoh Adat di Desa Bunga Karang Pada Tanggal 10 Agustus 2020 Pukul 15.00 Wib

${ }^{18}$ Op.cit, tgl 11 Agustus Pukul 09.00 2020 Wib

${ }^{19}$ Hasil Wawancara Dengan Nelayan di Desa Bunga Karang Pada Tanggal 11 Agustus 2020. Pukul 11.30 Wib
} 


\section{DAFTAR PUSTAKA}

\section{Buku}

Achmad Ichsan , Hukum Perdata IB, Jakrta, Pembimbing Masa, 1969

Kusnadi, Keberdayaan Nelayan \& Dinamika Ekonomi Pesisir, Jember. Ar-ruzz Media, 2009

I Ketut Oka Setiawan, Hukum Perikatan, Jakarta, Sinar Grafika, 2017

Soesilo,Pramudji, Kitab Undang-Undang Hukum Perdata, Rhedbook Publisher Buku Ke 3, 2008

Mariam Danu Badrul-zaman, Buku III Hukum Perikatan Dengan Penjelasan, Bandung, Alumni, 1983

Ny. Sri Soedewi M. Sofwan, Hukum Perutangan, terjemahan Verbintenissenrecht bagian dari Inleiding Nederlands

Burgerlijk Rccht oleh Mr. Dr. HFA Vollmar, Yogyakarta: Seksi Hukum Perdata Fak. Hukum UGM, 1975, lihat buku E. Utrecht, Pengantar Dalam Hukum Indonesia, Jakarta: Ikhtiar, cet. IV, 1957

Nm Wahyu Kuncoro, Resiko Jual Beli Property, Jakarta, Raih Asa Sukses. 2015

Ni Kadek Ayu Ena Widiasih, I Made Sarjana. Risalah Lelang Sebagai Akta Otentik Pengganti Akta Jual Beli Dalam Lelang. Journal Ilmu Hukum.Bali, 2016

Retna Gumanti, Syarat Sahnya Perjanjian (Ditinjau Dari KUHPerdata). Jurnal Pelangi Ilmu.Vol 05, 2012

RM. Suryodiningrat, Azas-Azas Hukum Perikatan, Bandung: Tarsito, 1985

R. Soetojo Prawirohamidjojo, Hukum Perikatan, Surabaya, Bina Ilmu, 1979

Soekanto, Soejono, Pengantar Penelitian Hukum, Universitas Indonesia (UI) Press, Jakarta 1986

Subekti dan R. Tjiptasudibio, Kitab Unidang-undang Hukum Perdata terjemahan Burgerlijk Wetboek

Suyanto, Hapusnya Hak Atas Tanah Akibat Penitipan Ganti Rugi Dalam Pengadaan Tanah Untuk Kepentingan Umum, Surabaya, cv Jagad Publishing, 2020 